\title{
Influence of Pine Bark Substrate Age on Performance and Leaching of Nursery Preemergence Herbicides
}

\author{
Cody J. Stewart and S. Christopher Marble ${ }^{1}$ \\ Department of Environmental Horticulture, University of Florida Institute of \\ Food and Agricultural Sciences, Mid-Florida Research and Education \\ Center, 2725 South Binion Road, Apopka, FL 32703
}

\section{Brian Jackson}

Department of Horticultural Science, North Carolina State University, 130 Kilgore Hall, Raleigh, NC 27695

Brian J. Pearson

Department of Environmental Horticulture, University of Florida Institute of Food and Agricultural Sciences, Mid-Florida Research and Education Center, 2725 South Binion Road, Apopka, FL 32703

\section{P. Christopher Wilson}

Soil and Water Sciences Department, University of Florida, 2181 McCarty Hall, Gainesville, FL 3261

\author{
Dwight K. Lauer \\ Silvics Analytic, 122 Todd Circle, Wingate, NC 28174
}

Additional index words. preemergence, postemergence, soilless substrate, pine bark, substrate age, ornamental

\begin{abstract}
The objective of these experiments was to determine if preemergence herbicides perform similarly across pine bark that was aged for varying lengths of time including 0 , 4, 8, and 12 months after bark removal from harvested trees. Three preemergence herbicides were evaluated for three separate weed species, including 1) Cardamine flexuosa With. (bittercress) with isoxaben, 2) Digitaria sanguinalis (L.) Scop. (large crabgrass) with prodiamine, and 3) Oxalis stricta $L$. (woodsorrel) with dimethenamid-P. Leaching of herbicides through substrates was evaluated for prodiamine. Weed growth in the various substrates was variable, but few differences were detected in weed growth among the pine bark substrates evaluated. For isoxaben and prodiamine, weed control was similar among the pine bark substrates in most cases when label rates were applied. Although some differences were detected in prodiamine performance across different pine bark ages, a high level of control was achieved in all cases at rates well below manufacturer recommendations. Prodiamine leaching was minimal in all substrates. It would be recommended that growers test substrates for physical properties before use so that irrigation and other production inputs could be modified if needed. In most cases, growers should expect similar performance of preemergence herbicides regardless of pine bark substrate age.
\end{abstract}

In the eastern United States, pine bark is the predominate substrate component in outdoor nursery container plant production. Pine bark is a byproduct of the timber industry and is stripped off logs following harvest. Once the removed pine bark is acquired by a bark processor, it is generally processed and stored in piles/windrows and turned as needed to facilitate the breakdown of the particles and to reduce excessive heat buildup (Fields et al., 2014). There are currently no industry or governmental regulations or guidelines for the processing, handling, and aging of pine

Received for publication 15 Nov. 2018. Accepted for publication 4 Mar. 2019.

${ }^{1}$ Corresponding author. E-mail: marblesc@ufl.edu. aging, and time of year the trees were harvested may also influence the final product's chemical and physical properties. Most ornamental plant container growers use aged pine bark, which has generally been shown to be uniform in physical properties and ideal for plant growth (Harrelson et al., 2004; Pokorny, 1979). However, there is an increasing interest in the use of fresh or "green" pine bark because it weighs less and thus reduces shipping costs (Fields et al., 2012; Kaderabek et al., 2016). In many cases, growers may be unaware of how their pine bark has been processed, handled, or aged or what differences there may be in physical/chemical properties from different sources or "batches" of bark from the same supplier. There has been a considerable amount of research conducted over the past few decades on how to manage production inputs based on substrate properties (Bilderback et al., 2005); however, few studies have focused on how changes in substrate properties may impact weed growth and/or preemergence herbicide performance. As growers must produce weed-free plants to meet consumer demand (Simpson et al., 2002), it is important to know if these herbicides perform differently based on the substrates to which they are applied.

Wehtje et al. (2009) evaluated prodiamine, flumioxazin, and isoxaben when applied to pine bark compared with WholeTree and clean chip residual, byproducts of the forest industry. The authors reported similar germination of spotted spurge (Euphorbia maculata L.), large crabgrass (Digitaria sanguinalis L.), and eclipta (Eclipta prostrata L.) in all substrates evaluated. Data also showed that herbicides performed similarly across all substrates at labeled rates. The particle size of horticultural substrates has been shown to affect the germination and growth rate of weed seeds in some instances. Wada (2005) demonstrated that as substrate particle size increased, the germination rate and growth of pearlwort (Sagina procumbens L.), northern willowherb (Epilobium cilatum Raf.), and common groundsel (Senecio vulgaris L.) decreased. Similarly, a study conducted by Keddy and Constabel (1986) demonstrated that species with small seeds had higher germination rates and greater growth rates in soils with smaller particle sizes when compared with soils with larger particle sizes. The observations from both of these studies are significant, as many of the common weed species found in container production have small seeds. However, many weed species have the ability to germinate across a wide range of moisture and water tension levels (Bullied et al., 2012), thus increased moisture holding capacity is unlikely to result in a direct increase in germination of all weed species. Altland and Boldt (2018) evaluated creeping woodsorrel (Oxalis corniculata L.) germination in pine bark substrates amended with sphagnum peatmoss at ratios including 100:0, 80:20, and 60:40 and found that although water 
holding capacity increased with increasing peatmoss percentage, there was no effect on creeping woodsorrel germination.

Leaching of herbicides in different growing substrates has also been previously investigated. Most of the research on leaching of preemergence herbicides labeled for use on nursery crops demonstrate that they are highly adsorptive to horticultural substrates. Research focusing on metolachlor has shown that it is tightly bound to organic substrates (Grey et al., 1996; Koncal et al., 1981; Mahnken et al., 1994). One of the most common preemergence herbicides in nursery production, oxyfluorfen, has been shown to be more mobile in pine bark than peat; however, it was largely immobile in both substrates (Case et al., 2005; Horowitz and Elmore, 1991). A study conducted by Simmons and Derr (2007) demonstrated that there was greater pendimethalin leaching in pine bark compared with a Tetotum fine loam field soil. In this study, pendimethalin leached to a depth of 6 to $9 \mathrm{~cm}$ compared with less than $3 \mathrm{~cm}$ in field soil based on a large crabgrass bioassay conducted with soil columns. Simmons and Derr (2007) concluded that increased mobility of pendimethalin was likely due to larger particle size and void space in the pine bark substrate, which increased hydraulic conductivity compared with field soil. In contrast, Robertson and Derr (2017) reported less leaching of dimethenamid-P in pine bark compared with field soil. Due to a lack of information on how herbicides perform on pine bark of varying ages and physical properties, and previous work showing that substrate components can significantly impact leaching (Mahnken et al., 1994), the objective of these experiments was to determine if age influences performance and leaching of commonly used preemergence herbicides when applied to pine bark substrates.

\section{Materials and Methods}

Three experiments were conducted in Apopka, FL, in 2016. Pine bark aging, handling, sampling procedures, and physical and chemical properties of all substrates evaluated have been reported previously (Kaderabek et al., 2016). Briefly, fresh longleaf pine bark (Pinus palustris L.), was

Table 1. Treatment dates and substrates used in three greenhouse experiments evaluating preemergence herbicide efficacy in 2016.

\begin{tabular}{lcc}
\hline Expt. 1 & Expt. 2 & Expt. 3 \\
\hline 3 Feb. & Treatment dates & \\
24 Feb. & 23 June & 4 Nov. \\
& 7 July & 18 Nov. \\
0 mo. & Substrates evaluated & \\
4 mo. & 8 mo. & 12 mo. \\
Std. & Std. & Std. \\
Peat & Peat & Peat \\
\hline
\end{tabular}

${ }^{\mathrm{z}}$ Substrate $0,4,8$, and $12 \mathrm{mo} .=$ pine bark aged for $0,4,8$, and 12 months, respectively. Std. = standard pine bark substrate obtained from local supplier of unknown age. peat $=$ peat: perlite $(80: 20 \mathrm{v}: \mathrm{v})$ mix. hammer milled through a 1.6-cm screen, placed in three replicate piles $(17 \mathrm{~m}$ long $\times$ $10 \mathrm{~m}$ wide $\times 3.3 \mathrm{~m}$ tall) each containing $\approx 250 \mathrm{~m}^{3}$, and turned every 4 weeks for a period of 12 months. Samples were taken from the aging piles every month, after turning, for a period of 1 year. At each sampling date, samples were composites of multiple subsamples from all three pine bark piles and were pulled from below the surface of the piles. Sampling and sample storage procedures were based on methods outlined in the US Composting Council's Test Methods for the Examination of Composting and Compost (Thompson, 2002) and more thoroughly described by Kaderabek (2017). Briefly, stratified subsamples (3 L) were taken from different heights (top, middle, and bottom) and horizontal depths $(0.3,0.6$, 0.9 , and $1.2 \mathrm{~m}$ ) within each sampled pile. This sampling procedure accounts for variation within a pile and reduces possible errors due to stratification of constituents and conditions within the piles (Breitenbeck and Schellinger, 2004). Samples were stored indoors in sealed, 4-mm polyethylene bags at $4{ }^{\circ} \mathrm{C}$ to minimize moisture and microbial changes before samples were shipped to Apopka for herbicide evaluation on three separate dates (Table 1). The time between sampling and shipping of the bark substrates was never more than 1 week. This allowed greenhouse trials evaluating herbicide performance to be conducted immediately on substrate arrival and removed potential variability, as it is unknown how physical or chemical properties may change during longterm storage, or what the most appropriate storage protocol would be to maintain trial integrity.

As pine bark samples were used in experiments as soon as they were received, two reproducible substrates were used for comparison in each of the three experiments. An industry "standard" pine bark substrate (100\% bark) was obtained from a Florida supplier on two separate occasions (first for Expts. 1 and 2, secondly for Expt. 3) that had been handled and processed similarly to the pine bark in NC. The age of this substrate was unknown but was estimated to have been aged for $\approx 4$ to 6 months. In terms of pine bark, there is no true industry "standard"; growers may prefer bark that is aged, fresh, or screened to a specific size depending on their needs and production practices. This standard substrate was included to have a readily available and widely used pine bark substrate for comparison with barks of known ages. Additionally, a peat:perlite (80:20 v:v) was also used for comparison in each experiment along with the standard. The peat:perlite substrate was chosen as it was readily reproducible. Before use in weed efficacy studies, $\mathrm{pH}$ was measured on all substrates with a pH/EC meter (9813-6; Hannah Instruments, Ann Arbor, MI) and dolomitic lime was added via incorporation as needed to bring substrate $\mathrm{pH}$ level to 5.5. Fertilizer [Osmocote Blend (8-9 months) 17-2.2P9.1K (ICL Inc., Dublin, OH)] was then incorporated into each substrate using a soil mixer at a rate of $4.4 \mathrm{~kg} \cdot \mathrm{m}^{-3}$ based on manufacturer recommendations. These procedures were repeated for all experiments and all experiments were repeated (Table 1).

Particle size distribution of each pine bark substrate was determined using methods previously described (Jackson et al., 2009). Briefly, $100 \mathrm{~g}$ of air-dried samples were determined using soil sieves plus a bottom pan (Table 2). Sieves and pan were shaken for 10 min with a RX-29 Ro-Tap sieve shaker (278 oscillations/min, 150 taps/min; W.S. Tyler, Mentor, $\mathrm{OH}$ ) and the particle fractions retained on each sieve and the amount that passed through the smallest sieve and retained by the sieve pan was weighed.

Table 2. Particle size distribution of standard and aged pine bark (PB) substrates used in herbicide efficacy trials.

\begin{tabular}{|c|c|c|c|c|c|c|}
\hline \multirow[b]{3}{*}{ Sieve $(\mathrm{mm})^{\mathrm{w}}$} & \multicolumn{6}{|c|}{ Particle size distribution $(\%)^{\mathrm{z}}$} \\
\hline & \multicolumn{2}{|c|}{ Standard $\mathrm{PB}^{\mathrm{y}}$} & \multicolumn{4}{|c|}{ Aged $\mathrm{PB}^{\mathrm{x}}$} \\
\hline & Expt. 1-2 & Expt. 3 & $0 \mathrm{mo}$. & $4 \mathrm{mo}$. & $8 \mathrm{mo}$. & $12 \mathrm{mo}$. \\
\hline$>6.3$ & 30.3 & 22.3 & 34.0 & 18.6 & 12.3 & 16.4 \\
\hline $6.3-2.0$ & 44.3 & 47.0 & 45.1 & 41.5 & 31.0 & 36.0 \\
\hline $2.0-0.71$ & 16.0 & 19.6 & 13.7 & 21.4 & 22.8 & 22.1 \\
\hline $0.71-0.5$ & 2.4 & 3.2 & 2.8 & 6.5 & 10.6 & 8.7 \\
\hline $0.5-0.25$ & 2.9 & 3.4 & 2.9 & 7.2 & 14.5 & 11.0 \\
\hline $0.25-0.11$ & 2.7 & 2.5 & 1.6 & 3.6 & 4.6 & 4.4 \\
\hline$<0.11$ (pan) & 1.3 & 2.0 & 0.8 & 1.4 & 4.5 & 1.8 \\
\hline \multicolumn{7}{|l|}{ Texture $^{\mathrm{v}}$} \\
\hline Coarse & $74.6 \mathrm{a}^{\mathrm{u}}$ & $69.3 \mathrm{~b}$ & $79.1 \mathrm{a}$ & $60.1 \mathrm{c}$ & $43.3 \mathrm{e}$ & $52.3 \mathrm{~d}$ \\
\hline Medium & $18.4 \mathrm{~d}$ & $23.8 \mathrm{c}$ & $16.4 \mathrm{~d}$ & $28.0 \mathrm{~b}$ & $33.3 \mathrm{a}$ & $30.7 \mathrm{ab}$ \\
\hline Fine & $6.9 \mathrm{de}$ & $7.9 \mathrm{~d}$ & $5.3 \mathrm{e}$ & $12.2 \mathrm{c}$ & $23.7 \mathrm{a}$ & $17.2 \mathrm{~b}$ \\
\hline
\end{tabular}

${ }^{\mathrm{z}}$ Particle size distribution calculated on a dry weight basis using means of three air-dried samples.

${ }^{\mathrm{y}}$ Standard PB was handled and processed similarly to PB obtained from North Carolina, but age was unknown and was used for comparison purposes.

${ }^{\mathrm{x}}$ Aged PB was taken at 4-month intervals from a supplier in North Carolina and shipped to Florida for evaluation. PB handling, sampling, and aging is described in Kaderabek et al., 2016.

${ }^{\mathrm{w}} 1 \mathrm{~mm}=0.0394$ inch.

${ }^{\mathrm{v}}$ Texture grouping: coarse $=$ greater than $2.0 \mathrm{~mm}$; medium $=$ greater than 0.5 to less than $2.0 \mathrm{~mm}$; fine $=$ less than $0.5 \mathrm{~mm}$.

"Means within a row followed by the same letter are not significantly different based on Fisher's protected least significant difference $(P \leq 0.05)$. 
Dose-response studies. Amended substrates were used to fill 0.5 -L nursery containers. After filling, containers were placed in a greenhouse and received $1.3 \mathrm{~cm}$ of irrigation every day via overhead sprinklers. After one irrigation event, containers were removed from the greenhouse and herbicides including prodiamine (Barricade 4FL; Syngenta Crop Protection, LLC, Greensboro, NC), isoxaben (Gallery SC; Dow AgroSciences LLC, Indianapolis, IN), and dimethenamid-P (Tower 6.0EC; BASF Corp., Research Triangle Park, NC) were applied using a $\mathrm{CO}_{2}$ backpack sprayer equipped with a 8004 flat fan nozzle (TeeJet Technologies, Wheaton, IL) and calibrated to deliver $468 \mathrm{~L} \cdot \mathrm{ha}^{-1}$ at $241 \mathrm{kpa}$. Prodiamine and dimethenamid-P were applied at 0.21 , $0.45,0.85,1.7$, and $3.4 \mathrm{~kg}$ a.i./ha while isoxaben was applied at $0.14,0.28,0.55$, 1.1 and $2.2 \mathrm{~kg}$ a.i./ha. These rates correspond with $0.125,0.25,0.5,1$, and $2 \times$ the highest recommended label rate of each herbicide. Different bioassay species were chosen for each a.i.: large crabgrass was chosen for prodiamine, woodsorrel (Oxalis stricta L.) was chosen for dimethenamid-P, and bittercress (Cardamine flexuosa With.) for isoxaben. Weed species were chosen based on their prevalence in Florida nurseries and their sensitivity to the herbicides used in the study. Seeds of each species (30) were surface sown to containers $2 \mathrm{~d}$ after herbicides were applied. Pots were then grouped by species in a completely randomized design with eight single pot replications per herbicide rate. Nontreated controls were maintained for all substrates for comparison purposes. After 10 weeks, weeds were clipped at the substrate surface and fresh weights were determined.

Leaching study. Column leaching through substrates was accomplished using the segmented column technique (Weber et al., 1986; Wehtje et al., 2012; Wu and Santelman, 1975). This technique is more economical than chemical assay and can be very sensitive if proper species are chosen for the herbicide being evaluated (Lavy and Santelmann, 1986). Polyvinyl chloride pipe (7.5-cm diameter) was cut into four $3-\mathrm{cm}$ sections and one $5-\mathrm{cm}$ section and duct taped together to yield a $17-\mathrm{cm}$-tall column. The four $3-\mathrm{cm}$ sections were added to the top of the column so that leaching could be evaluated at depths of 0 to 3,3 to 6,6 to 9,9 to 12 , and 12 to $17 \mathrm{~cm}$. Nursery ground cloth was cut and secured to the bottom of the columns with zip ties. Enough columns were prepared for each experiment so that each substrate was replicated four times (four columns). Columns were then filled with the substrates described previously by adding in small volumes of substrate to the columns and then tapping the columns on a counter 30 times until the entire column was uniformly packed. Columns were secured together with tape to ensure they did not tip over and then placed in nursery containers for transport to the greenhouse. The columns remained in the containers while in the greenhouse and were irrigated $1.3 \mathrm{~cm}$ per day for $7 \mathrm{~d}$ to allow for further substrate settling. At this time, prodiamine was applied at a rate of $1.7 \mathrm{~kg}$ a.i./ha over the top of the columns on the substrate surface using the methods described previously. After treatment, columns remained in the greenhouse for 2 weeks under the same irrigation scheduling, receiving $17.8 \mathrm{~cm}$ irrigation in total. At this time, a knife was used to cut through the taped joints and cut columns into five segments. When a segment was cut, a metal spatula was placed underneath the segment of the pipe, and the substrate inside the pot was placed into small $7.6-\mathrm{cm}$ round plastic pots. For each column, this yielded five containers representing depths described previously. Approximately 25 large crabgrass seeds were then surface sown to all the pots to determine prodiamine leaching at the various column depths. Crabgrass was chosen as the bioassay species, as many Digitaria spp. have shown high sensitivity to prodiamine (Duray and Davies, 1987; Johnson, 1996). After seeding, containers were kept inside the greenhouse for 4 weeks, at which time shoot weights were determined by clipping the crabgrass at the substrate surface and weighing. All columnleaching trials were completely randomized with four replications (columns) for each substrate. Four replications for each substrate were not treated with any herbicide and used for comparison. All column-leaching studies were repeated (Table 1).

Statistical analysis. Shoot weight data from nontreated controls in each experiment and round were subjected to analysis of variance (ANOVA) with the use of the general linear model procedure in SAS (version 9.4; SAS Institute, Cary, NC). Fisher's protected least significant difference (LSD) test $(P=0.05)$ was used to compare growth of each weed species based on substrate. Particle size distribution data were analyzed similarly. Although multiple soil sieves were used, particle sizes were placed into three groups including coarse $(>2.0 \mathrm{~mm})$, medium $(0.5$ to $2.0 \mathrm{~mm})$, and fine $(<0.5 \mathrm{~mm})$ for statistical comparison.

Table 3. Shoot fresh weight ${ }^{\mathrm{z}}$ of three container weed species as influenced by substrate.

\begin{tabular}{|c|c|c|c|c|c|c|}
\hline \multirow[b]{2}{*}{ Substrate $^{y}$} & \multicolumn{2}{|c|}{ Bittercress } & \multicolumn{2}{|c|}{ Large crabgrass } & \multicolumn{2}{|c|}{ Oxalis } \\
\hline & Round 1 & Round 2 & Round 1 & Round 2 & Round 1 & Round 2 \\
\hline & & & Expt. 1 & & & \\
\hline $0 \mathrm{mo}$. & $6.4 \mathrm{~b}^{\mathrm{x}}$ & $4.1 \mathrm{a}$ & $22.4 \mathrm{ab}$ & $23.0 \mathrm{~b}$ & $6.2 \mathrm{~b}$ & $6.1 \mathrm{~b}$ \\
\hline 4 mo. & $7.5 \mathrm{ab}$ & $3.2 \mathrm{~b}$ & $20.2 \mathrm{~b}$ & $30.5 \mathrm{a}$ & $8.3 \mathrm{a}$ & $8.3 \mathrm{a}$ \\
\hline Std. & $3.6 \mathrm{c}$ & $2.2 \mathrm{c}$ & $19.7 \mathrm{~b}$ & $17.4 \mathrm{~b}$ & $4.5 \mathrm{~b}$ & $3.8 \mathrm{c}$ \\
\hline Peat & $8.9 \mathrm{a}$ & $4.2 \mathrm{a}$ & $\begin{array}{r}27.2 \mathrm{a} \\
\text { Expt. } 2\end{array}$ & $33.3 \mathrm{a}$ & $8.8 \mathrm{a}$ & $8.2 \mathrm{a}$ \\
\hline $8 \mathrm{mo}$. & $4.5 \mathrm{a}$ & $2.5 \mathrm{~b}$ & $14.4 \mathrm{a}$ & $9.8 \mathrm{a}$ & $4.4 \mathrm{~b}$ & $4.6 \mathrm{a}$ \\
\hline Std. & $2.6 \mathrm{~b}$ & $3.3 \mathrm{ab}$ & $12.7 \mathrm{a}$ & $5.6 \mathrm{~b}$ & $4.1 \mathrm{~b}$ & $3.7 \mathrm{a}$ \\
\hline Peat & $4.3 \mathrm{a}$ & $4.4 \mathrm{a}$ & $\begin{array}{r}12.5 \mathrm{a} \\
\text { Expt. } 3\end{array}$ & $11.5 \mathrm{a}$ & $6.6 \mathrm{a}$ & $4.5 \mathrm{a}$ \\
\hline $12 \mathrm{mo}$. & $3.9 \mathrm{~b}$ & $3.3 \mathrm{a}$ & $6.8 \mathrm{a}$ & $6.2 \mathrm{a}$ & $3.9 \mathrm{ab}$ & $2.9 \mathrm{~b}$ \\
\hline Std. & $5.0 \mathrm{~b}$ & $4.8 \mathrm{a}$ & $6.1 \mathrm{a}$ & $6.0 \mathrm{a}$ & $2.9 \mathrm{~b}$ & $3.9 \mathrm{ab}$ \\
\hline Peat & $7.0 \mathrm{a}$ & $3.3 \mathrm{a}$ & $7.4 \mathrm{a}$ & $5.9 \mathrm{a}$ & $5.9 \mathrm{a}$ & $4.2 \mathrm{a}$ \\
\hline
\end{tabular}

${ }^{\mathrm{z}}$ Fresh weights were harvested at 10 weeks after seeding in all trials.

${ }^{\mathrm{y}}$ Substrate $0,4,8$, and 12 mo. = pine bark aged for $0,4,8$, and 12 months, respectively. Std. $=$ standard pine bark substrate obtained from local supplier of unknown age, peat $=$ peat: perlite $(80: 20 \mathrm{v}: \mathrm{v})$ mix. All substrates included $4.4 \mathrm{~kg} \cdot \mathrm{m}^{-3}$ of Osmocote $17-5-11$ via incorporation.

${ }^{\mathrm{x}}$ Means within a column and experiment followed by the same letter are not significantly different according to Fisher's protected least significant difference $(P=0.05)$. 
Table 4. Estimated ED80 values for $80 \%$ shoot growth inhibition three preemergence herbicides applied to multiple horticultural growth substrates.

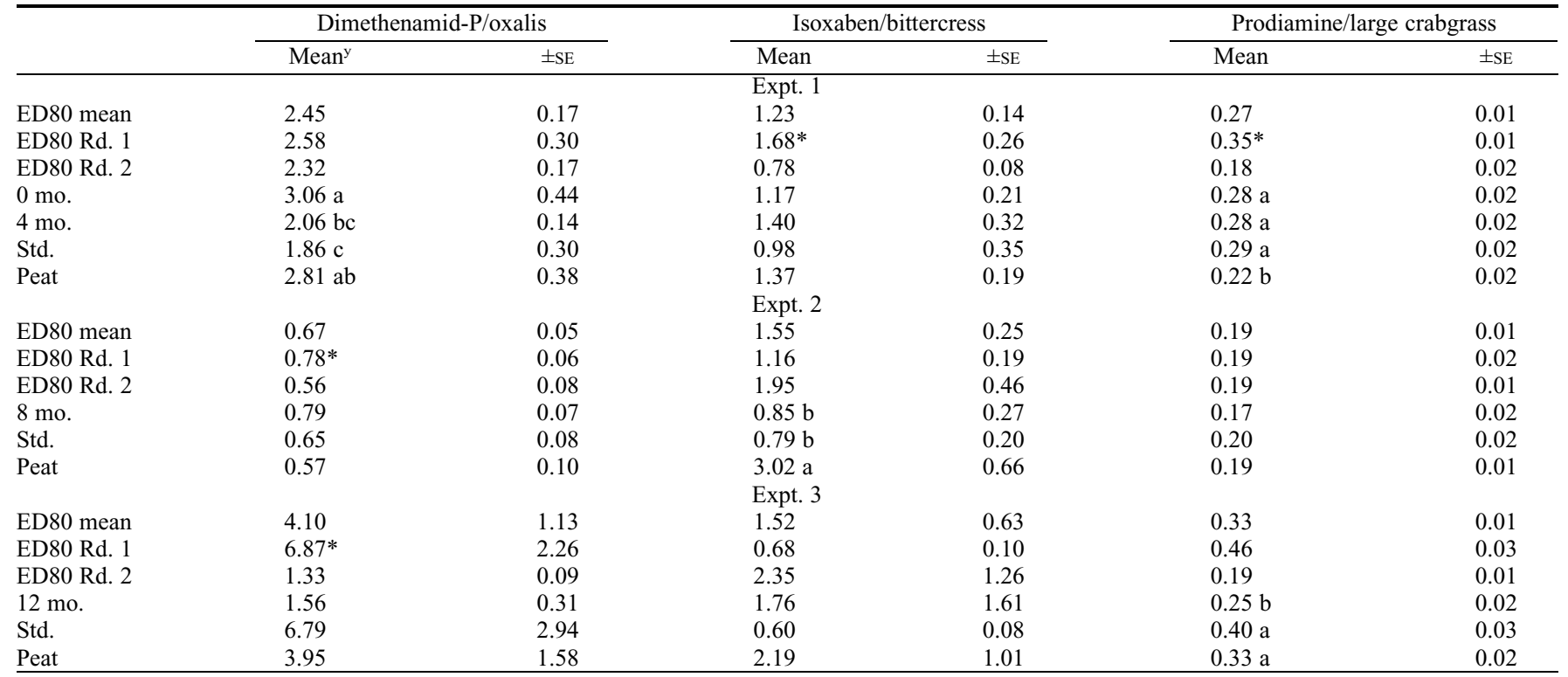

${ }^{\bar{z}}$ Substrate $0,4,8$, and 12 mo. = pine bark aged for $0,4,8$, and 12 months, respectively. Std. = standard pine bark substrate obtained from local supplier of unknown age; peat $=$ peat: perlite $(80: 20 \mathrm{v}: \mathrm{v})$ mix. All substrates included $4.4 \mathrm{~kg} \mathrm{~m}^{-3}$ of Osmocote 17-5-11 via incorporation.

${ }^{\mathrm{y}}$ Means within a column and experiment followed by the same letter are not significantly different according to Fisher's protected least significant difference $(P=$ $0.05)$. Asterisk $(*)$ shows significant differences between average ED80 values between rounds.

For column-leaching studies, data were converted to percent shoot weight of the nontreated control before analysis. Data were subjected to ANOVA using SAS and arcsine transformed as needed to meet the assumptions of ANOVA. Means from each column depth were separated using Fisher's LSD $(P=0.05)$. A Student $t$ test was used to determine differences between shoot weights of treated vs. nontreated columns at each depth evaluated.

\section{Results}

Particle size distribution. The standard bark substrate used in Expts. 1 and 2 (75\%) and the 0 month substrate $(79.1 \%)$ contained a higher percentage of coarse particles than any other substrate (Table 2). The standard substrate used in Expt. 3 had the next highest percentage of coarse particles $(69 \%)$, and the 8 - and 12 -month bark had the lowest at $43 \%$ and $52 \%$, respectively. The 8 -month bark also had the highest percentage of medium particles $(33 \%)$, although the 12-month bark was similar (31\%). The 8-and 12-month bark had the highest percentage of fine particles. The decrease in fine particles over time (months) has been reported in previous studiues and is likely attributed to microbial/ biological degradation of the bark particles over time and the breakage of particles during each of the turning/handling activities over time (Kaderabek, 2017).

Weed growth/shoot fresh weight. Due to significant round $\times$ substrate interactions, results for each experiment were analyzed by round. In both rounds of Expt. 1, bittercress growth was reduced in the standard bark substrate compared with other substrates evaluated (Table 3 ). Bittercress growth was generally greatest in the peat substrate, but

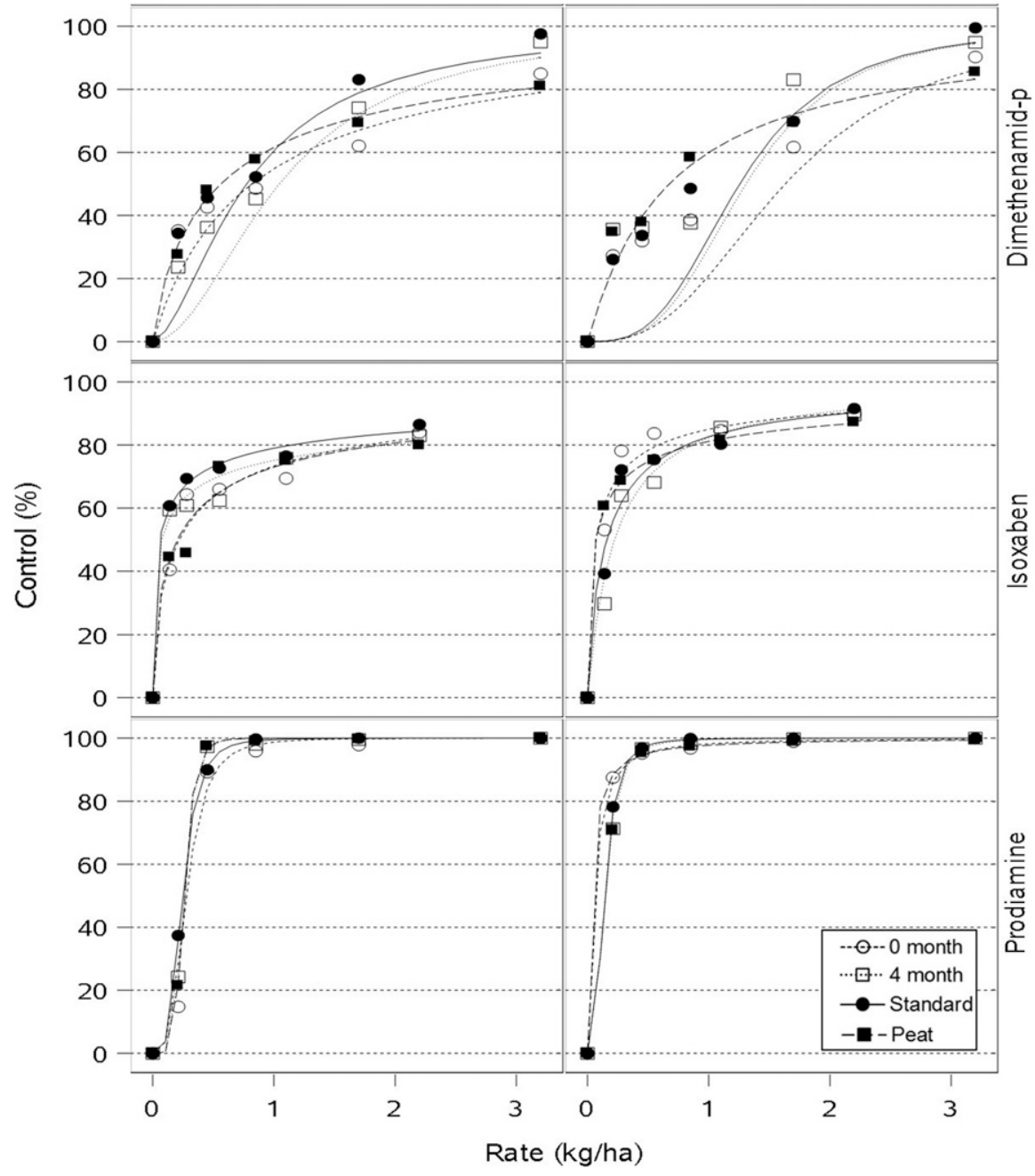

Fig. 1. Percent reduction in shoot fresh weight of oxalis (dimethenamid-P), bittercress (isoxaben), and large crabgrass (prodiamine) in response to herbicide rate and substrate for round 1 (left) and 2 (right) in Expt. 1. Substrates included pine bark that had been aged for 0 month, 4 months, a standard pine bark from local supplier of unknown age (standard), and a peat:perlite (80:20 v:v) substrate (peat). 
use of 4-month and 0-month pine bark resulted in similar growth in rounds 1 and 2 , respectively. Use of the standard bark substrate also resulted in less growth in round 1 of Expt. 2. In Expt. 3, no differences were detected between the standard bark substrate and the 12-month substrate in round 1 and bittercress grew similar in all substrates in round 2. Fewer differences were noted in crabgrass and oxalis throughout the trial. For crabgrass, there were no differences detected in any pine bark substrate in round 1 of Expt. 1, round 1 of Expt. 2, or in Expt. 3. For oxalis, some differences were observed in substrates in Expt. 1, most notably the reduced growth that occurred in the standard substrate in round 2. Oxalis growth was also greater in 4-month pine bark compared with 0-month bark in Expt. 1. However, pine bark substrates resulted in similar growth in Expts. 2 and 3.

Dose-response experiments. There were significant differences in ED80 for dimethenamid-p (woodsorrel) based on substrate in Expt. 1 (Table 4), and significant round and substrate $\times$ round interactions in Expts. 2 and 3. In Expt. 1, ED80 was significantly higher in both peat $\left(2.82 \mathrm{~kg} \cdot \mathrm{ha}^{-1}\right)$ and 0 -month $\left(3.06 \mathrm{~kg} \cdot \mathrm{ha}^{-1}\right)$ substrates compared with the standard $\left(1.86 \mathrm{~kg} \cdot \mathrm{ha}^{-1}\right)$, indicating a higher rate of dimethenamid-P was needed in peat and the 0 -month bark substrate to achieve $80 \%$ control. The log-logistic model did a poor job of fitting data from lower rate ranges in round 2 of Expt. 1 (Fig. 1) but curves were reasonable in the range of ED80 (Fig. 1). In Expt. 2, significant round $\times$ substrate interactions $(P=0.001)$ were caused by the 8-month substrate having the highest and lowest ED80 in round 1 and 2, respectively (Fig. 2). On average, no differences in ED80 of dimethenamid-p were observed in any of the three substrates evaluated in Expt. 2, and in general, dimethenamid-P provided better control across all substrates than was observed in other experiments. In Expt. 3, round $\times$ substrate interactions were mostly related to poor control achieved when dimethenamid$\mathrm{P}$ was applied to the standard substrate and $80 \%$ control was not achieved (Fig. 3 ).

The only significant differences in ED80 for isoxaben (bittercress) were due to round $(P=0.001)$ in Expt. 1 and substrate $(P=$ 0.005 ) in Expt. 2 (Table 3). In Expt. 1, the higher isoxaben rate was required for round 1. In Expt. 2, a higher rate of isoxaben was needed for $80 \%$ bittercress control when applied to the peat substrate $\left(3.02 \mathrm{~kg} \cdot \mathrm{ha}^{-1}\right)$ compared with the 8 -month $\left(0.85 \mathrm{~kg} \cdot \mathrm{ha}^{-1}\right)$ or standard substrate $\left(0.79 \mathrm{~kg} \cdot \mathrm{ha}^{-1}\right)$. In Expt. 3, the lack of significant differences were in part due to a greater degree of variation in control observed for different substrates (Fig. 3). Graphs comparing predicted percent control to percent control calculated from treatment means (Fig. 1-3) suggest the log-logistic model described the data reasonably well. However, isoxaben rates required to achieve $80 \%$ bittercress control sometimes exceeded the label rate.

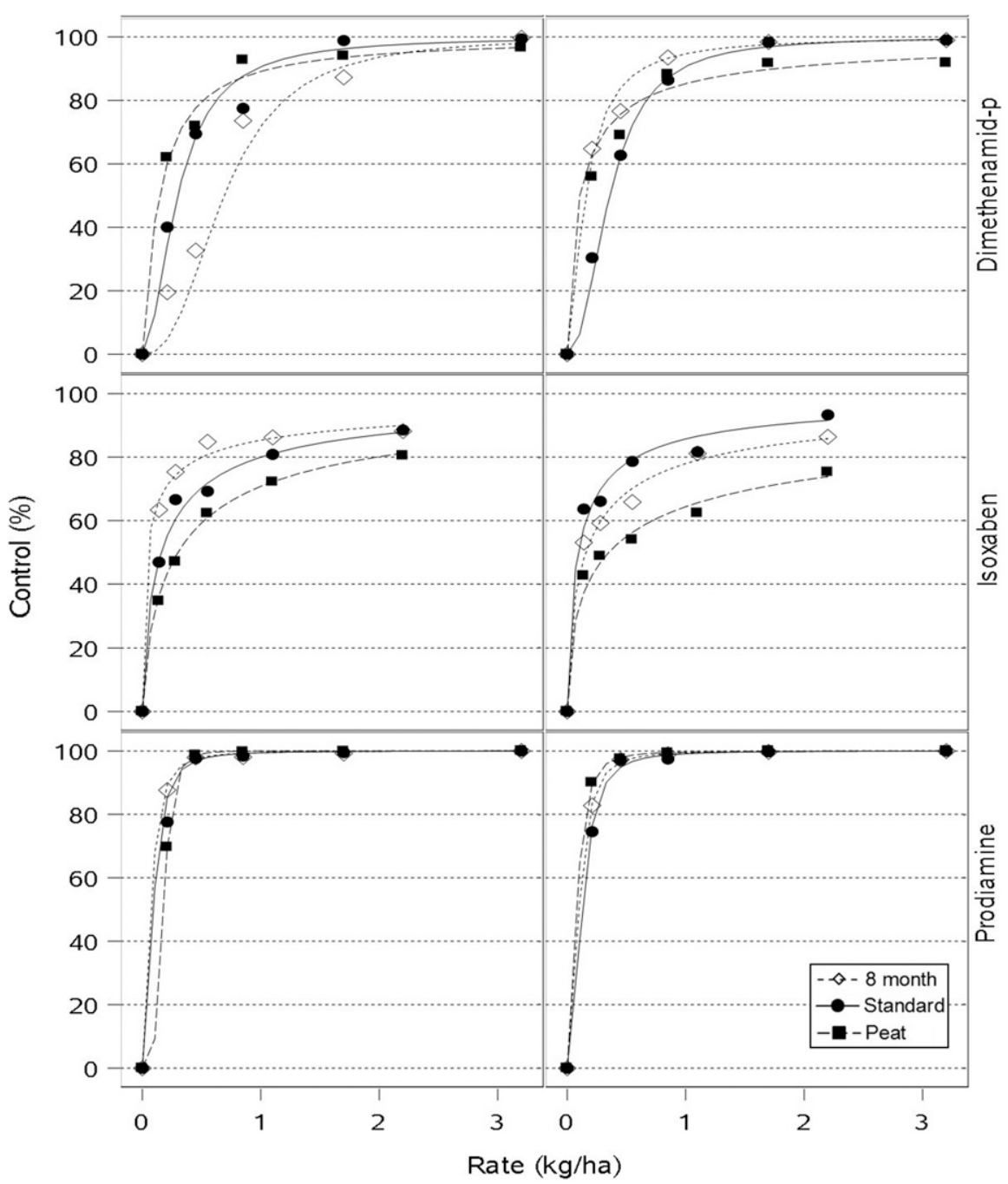

Fig. 2. Percent reduction in shoot fresh weight of oxalis (dimethenamid-P), bittercress (isoxaben), and large crabgrass (prodiamine) in response to herbicide rate and substrate for round 1 (left) and 2 (right) in Expt. 2. Substrates included pine bark that had been aged for 8 months, a standard pine bark from local supplier of unknown age (standard), and a peat:perlite $(80: 20 \mathrm{v}: \mathrm{v})$ substrate (peat).

For prodiamine and crabgrass, there were significant substrate and round effects in both Expts. 1 and 3, and significant round $\times$ substrate interactions in all three experiments. In Expt. 1, ED80 was lower for peat compared with the pine bark substrates, and in Expt. 3, 12-month substrate had a lower ED80 compared with peat or the standard. The ED80 for crabgrass occurred at very low rates for all substrates in all three experiments (Table 3) and were well below label recommendations. Significant differences were inconsequential as ED80 values were not consistent with substrate as indicated by the significant interaction and ranged from 0.19 to 0.40 across all experiments and substrates compared with a labeled use rates of up to $1.7 \mathrm{~kg} \cdot \mathrm{ha}^{-1}$.

Column-leaching experiments. In Expt. 1, all pine bark substrates treated with prodiamine showed reduced crabgrass growth at the 6- to 9-cm depth when compared with similar depths of nontreated columns (Table 5). Crabgrass shoot weight ranged from $48 \%$ to $61 \%$ of the control group at the 6- to $9-\mathrm{cm}$ depth. No differences were observed between crabgrass reduction in 0 to $3-\mathrm{cm}$ and $3-$ to $6-\mathrm{cm}$ depths in 0 -month pine bark or the standard pine bark. For peat, prodiamine leaching was minimal. Although no differences were detected in treated and nontreated columns in any but the top depth $(0-3 \mathrm{~cm})$, both 0 to $3 \mathrm{~cm}(7 \%$ of the nontreated control) and 3 to $6 \mathrm{~cm}(63 \%$ of the nontreated control) had reduced crabgrass shoot growth compared with the 9- to 12cm depth. In Expts. 2 and 3, minimal leaching occurred in all substrates. No differences between treated and nontreated columns were observed in 8-month, 12-month, standard, or the peat substrate at depths below 3 $\mathrm{cm}$. Further, no differences were observed within substrates when comparing crabgrass growth at depths ranging from 3 to $17 \mathrm{~cm}$.

\section{Discussion}

Few consistent trends were observed in weed growth within the different substrates. In several instances, weeds growing in the standard bark substrate (bittercress in Expt. 1, 
round 1, round 1 Expts. 2 and 3; large crabgrass in rounds 1 and 2, Expt. 1, round 2 Expt. 2; oxalis in round 1 and 2 Expt. 1) and the 0 -month substrate (large crabgrass in round 2 Expt. 1, oxalis in round 1 and 2 of Expt. 1) grew less than those in the peat substrate or other pine bark substrates. As all pots were irrigated similarly regardless of physical properties, greater growth in the peat or aged substrates may have been related to greater water holding capacity.

Overall, woodsorrel control with dimethenamid-P was variable in all three experiments, with average ED80 across all substrates ranging from 0.67 to $4.1 \mathrm{~kg} \cdot \mathrm{ha}^{-1}$. The reason for this variability is unknown, as

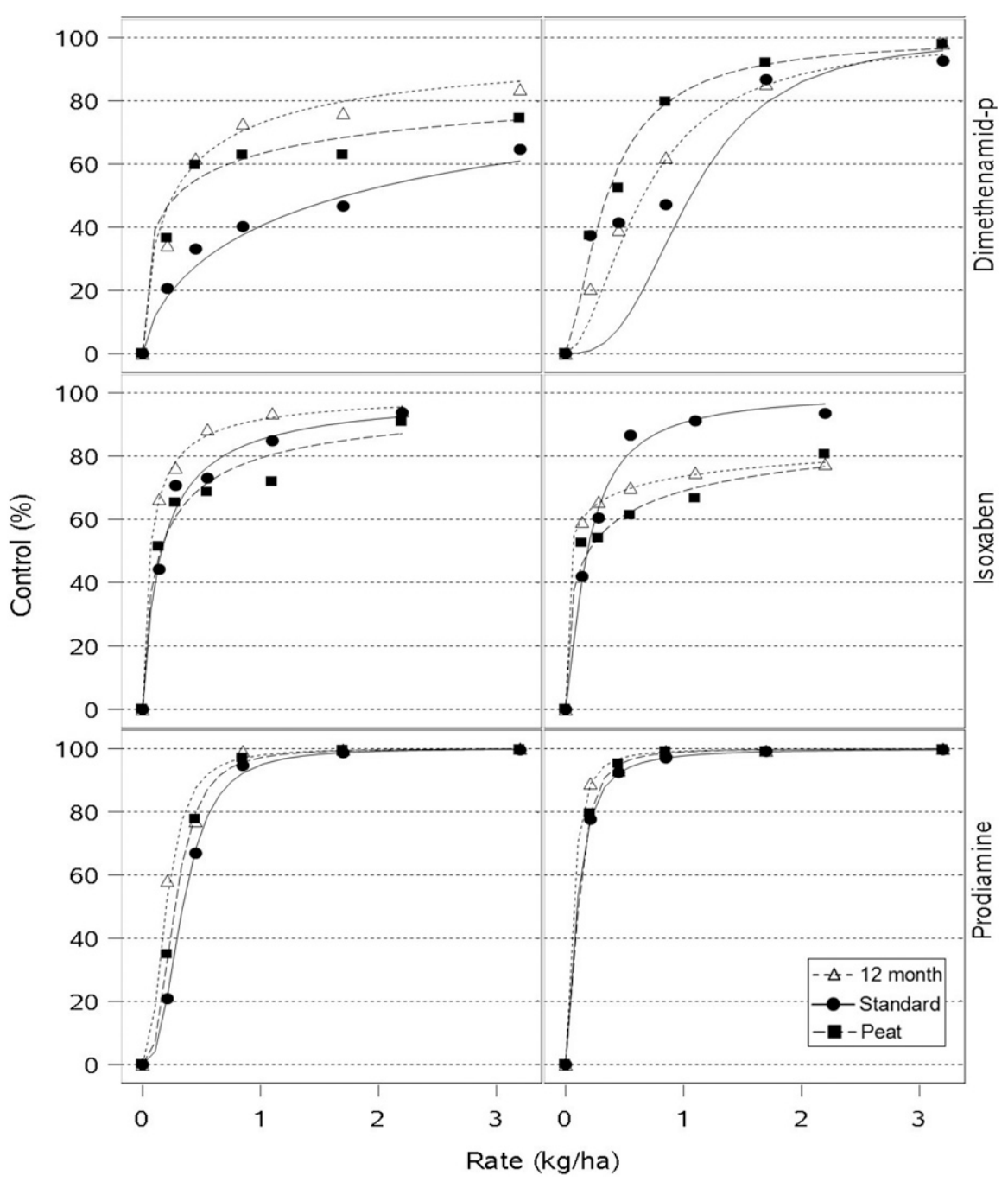

Fig. 3. Percent reduction in shoot fresh weight of oxalis (dimethenamid-P), bittercress (isoxaben), and large crabgrass (prodiamine) in response to herbicide rate and substrate for round 1 (left) and 2 (right) in Expt. 3. Substrates included pine bark that had been aged for 12 months, a standard pine bark from local supplier of unknown age (standard), and a peat:perlite (80:20 v:v) substrate (peat).
dimethenamid-P typically provides a high level of woodsorrel control (Neal et al., 2017). Although leaching potential was not assessed for dimethenamid-P, it is unlikely that significant leaching occurred in any of the substrates evaluated. Previous research has shown that dimethenamid-P is tightly bound to organic growth substrates (Robertson and Derr, 2017). In general, few differences were noted in dimethenamid-P efficacy on oxalis at label rates when aged pine bark was evaluated, with the exception of round 1 in Expt. 3.

Isoxaben performed similarly in all pine bark substrates across all three experiments. Use of peat as a substrate resulted in ED80 values that were higher than the label rate, but in most cases, growers would not use a peatbased substrate for outdoor container production. Differences that were observed would likely have no practical significance, as growers would likely achieve a high level of control with label rates.

No differences were observed in prodiamine leaching when comparing pine bark substrates in any experiment. However, prodiamine was detected at a greater depth in Expt. $1(6-9 \mathrm{~cm})$ compared with Expts. 2 and $3(0-3 \mathrm{~cm})$. Greater leaching is likely related to the larger particle sizes of the bark substrates used in Expt. 1. These results are similar to previous research by Simmons and Derr (2007) in which greater pendimethalin leaching was observed in pine bark compared with field soil due to greater pore space in pine bark. As a group, dinitroaniline herbicides, such as prodiamine, have low solubility and are less prone to leaching compared with many other herbicides (Senseman, 2007; Weber, 1990). These herbicides are also strongly sorbed to organic particles, such as a pine bark substrate. Weber (1990) concluded that as a group, downward leaching of dinitroaniline herbicides would be very rare, but would be possible in coarse-textured soils under high precipitation regimes. A higher percentage of coarse-textured particles in pine bark substrates used in Expt. 1, paired with frequent irrigation, may have caused greater prodiamine leaching than was expected.

It should be noted that all three experiments were conducted inside a temperaturecontrolled greenhouse and were irrigated similarly regardless of substrate physical

Table 5. Prodiamine movement in soilless pinebark substrates of different ages in comparison with an industry standard pinebark and peat:perlite substrates as indicated by large crabgrass bioassay.

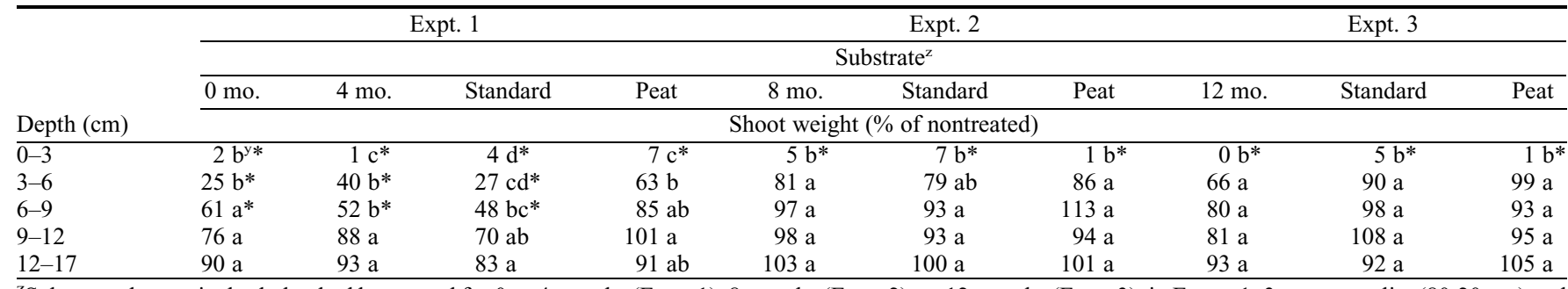

${ }^{\mathrm{z}}$ Substrate shows pinebark that had been aged for 0 or 4 months (Expt. 1), 8 months (Expt. 2), or 12 months (Expt. 3). in Expts. 1-3, a peat:perlite (80:20 v:v) and industry standard pinebark substrate of unknown age were used for comparison.

${ }^{\mathrm{y}}$ Means within a column followed the same letter are not significantly different according to Fisher's least significant difference $(P=0.05)$. Asterisk $(*)$ indicates significant difference in comparison with nontreated soil at a similar depth based on Student's $t$ test $(P=0.05)$. 
properties. Persistence and efficacy of herbicides in general are influenced by soil type, temperature, and soil moisture (Kulshrestha and Singh, 1992). Physical properties did vary with the substrates across the three experiments, as aging did occur (Kaderabek et al., 2016). In addition, peat is known to hold a significantly greater amount of available water compared with pine bark substrates that drain more readily due to greater particle sizes (Fields et al., 2014; Naasz et al., 2005; Verdonck et al., 1984), likely contributing to differences observed in weed growth among the substrates. As the peat substrate theoretically held a greater amount of moisture throughout the experiments, herbicides applied to this substrate could have been more prone to degradation through hydrolysis. Most nursery preemergence herbicides, including those evaluated in these experiments are primarily degraded by microbial activity (Senseman, 2007). However, microbial activity can be significantly influenced by soil moisture levels (Brockett et al., 2012). The higher ED80 values needed for the peat substrate in some instances were possibly related to higher soil moisture levels, whereas higher ED80 values required in pine bark substrates, specifically those that were not aged for multiple months, could be related more toward increased leaching due to larger particle sizes. In most instances, differences observed were of minimal practical importance, as satisfactory weed control was achieved in most substrates, specifically with isoxaben and prodiamine.

Overall, findings from these experiments are similar to those reported by Wehtje et al. (2009) in that few differences were observed in terms of herbicide performance across multiple horticultural substrates when herbicides were applied at recommended label rates. It is recommended that growers request or conduct physical property analysis of their chosen substrate before use so that irrigation and other production inputs can be modified if needed (Bilderback et al., 2005). It would also be recommended that growers work with pine bark suppliers to ensure consistent substrate materials so that weed growth and agrochemical performance could be more predictable over time. Although few differences were noted in weed control, growers may achieve more consistent crop growth with aged pine bark as has been reported previously (Harrelson et al., 2004).

\section{Literature Cited}

Altland, J.E. and J.K. Boldt. 2018. Influence of substrate physical properties on container weed germination. J. Environ. Hort. 36:1-6.

Bilderback, T.E., S.L. Warren, J.S. Owen, and J.P. Albano. 2005. Healthy substrates need physicals too! HortTechnology 15:747-751.

Breitenbeck, G.A. and D. Schellinger. 2004. Calculating the reduction in material mass and volume during composting. Compost Sci. Util. 12:365-371.

Brockett, B.F.T., C.E. Prescott, and S.J. Grayston. 2012. Soil moisture is the major factor influencing microbial community structure and enzyme activities across seven biogeoclimatic zones in western Canada. Soil Bio. Biochem. 44:9-20.

Bullied, W.J., P.R. Bullock, and R.C. Van Acker. 2012. Modelling soil water retention for weed seed germination sensitivity to water potential. Appl. Environ. Soil Sci. 2012:812561.

Case, L.T., H.M. Mathers, and A.F. Senesac. 2005. A review of weed control practices in container nurseries. HortTechnology 15:535-539.

Duray, S.A. and F.T. Davies. 1987. Efficacy of prodiamine for weed control in container grown landscape plants under high temperature production conditions. J. Environ. Hort. 5:82-84.

Fields, J.S., B.E. Jackson, and W.C. Fonteno. 2014. Pine bark physical properties influenced by bark source and age. 12 May 2018. <https:// www.ncsu.edu/project/woodsubstrates/documents/ research/pine-bark-physical-properties.pdf $>$.

Fields, J.S., B.E. Jackson, and W.C. Fonteno. 2012. Pine bark physical properties influenced by bark source and age. Comb. Proc. Intl. Plant Prop. Soc. 62:433-437.

Grey, T.L., G.R. Wehtje, B.F. Hajek, C.H. Gilliam, G.J. Keever, and P. Pace. 1996. Adsorption, mobility, and filtration of metolachlor in container media. J. Amer. Soc. Hort. Sci. 121:478-482.

Harrelson, T., S.L. Warren, and T.E. Bilderback. 2004. How do you manage aged versus fresh pine bark? South. Nurs. Assoc. Res. Conf. Proc. 49:63-66.

Horowitz, M. and C.L. Elmore. 1991. Leaching of oxyfluorfen in container media. Weed Technol. 5:175-180. Ingredient Indaziflam. 23 Nov. 2016. $<\mathrm{http}: / /$ www.bayercropscience.com/bcsweb/>.

Jackson, B.E. 2014. Substrate discrepancies. Nursery Mgt. 15 May 2018. <http://www.nurserymag. com/article/nm1014-pine-barkvariationsdifferences/ $>$.

Jackson, B.E., R.D. Wright, and J.R. Seiler. 2009. Changes in chemical and physical properties of pine tree substrate and pine bark during longterm nursery production. HortScience 44:791799.

Johnson, B.J. 1996. Effect of reduced dithiopyr and prodiamine rates on large crabgrass (Digitaria sanguinalis) control in common bermudagrass (Cynodon dactylon) and tall fescue (Festuca arundinacea) turf. WeedTech. 10:322-326.

Kaderabek, L.E. 2017. Effects of aging on the physical, chemical, and hydrologic properties of pine bark substrates. North Carolina State Univ., Raleigh, NC, Thesis.

Kaderabek, L., B.E. Jackson, and W. Fonteno. 2016. Changes in the physical, chemical, and hydrologic properties of pine bark over twelve months of aging. Intl. Plant Prop. Soc. Proc. 41:313-317.

Keddy, P.A. and P. Constabel. 1986. Germination of ten shoreline plants in relation to seed size, soil particle size and water level: An experimental study. J. Ecol. 74:133-141.

Koncal, J.J., S.F. Gorskey, and T.A. Fretz. 1981. Leaching of EPTC, alachlor, and metolachlor through a nursery medium as influenced by herbicide formulations. HortScience 16:757-758.

Kulshrestha, G. and S.B. Singh. 1992. Influence of soil moisture and microbial activity on pendi- methalin degradation. Bull. Environ. Contam. Toxicol. 48:269-274.

Lavy, T.L. and P.W. Santelmann. 1986. Herbicide bioassay as a research tool, p. 201. In: N.D. Camper (ed.). Research methods in weed science. 3rd ed. Weed Science Society of America, Lawrence, KS.

Mahnken, G.E., W.A. Skroch, T.J. Sheets, and R.B. Leidy. 1994. Metolachlor and simazine leaching through horticultural substrates. J. Environ. Hort. 12:55-58.

Naasz, R., J.C. Michel, and S. Charpentier. 2005. Measuring hysteretic hydraulic properties of peat and pine bark using a transient method. Soil Sci. Soc. Amer. J. 69:13-22.

Neal, J., J.C. Chong, and J. Williams-Woodward (eds.). 2017. 2017 southeastern pest control guide for nursery crops and landscape plantings. 15 June 2018. <https://content.ces.ncsu.edu/ southeastern-us-pest-control-guide-for-nurserycrops-and-landscape-plantings $>$.

Pokorny, F.A. 1979. Pine bark container mediaan overview. Intl. Plant Propagators' Soc. Combined Proc. 29:484-495.

Robertson, L. and J.F. Derr. 2017. Dimethenamid persistence and leaching potential in a soilless mix. J. Environ. Hort. 35:99-102.

Seefeldt, S.S., J.E. Jensen, and E.P. Fuerst. 1995. Log-logistic analysis of herbicide doseresponse relationships. WeedTech 9:218-227.

Senseman, S.A. 2007. Herbicide handbook, 9th edition. Weed Sci. Soc. Amer., Lawrence, KS.

Simmons, L.D. and J.F. Derr. 2007. Pendimethalin movement through pinebark compared to field soil. Weed Technol. 21:873-876.

Simpson, C.V., C.H. Gilliam, J.E. Altland, G.R. Wehtje, and J.L. Sibley. 2002. Postemergence oxalis control in container-grown crops. Southern Nurs. Assn. Res. Conf. 47:376-379.

Schabenberger, O. and F.J. Pierce. 2002. Contemporary statistical models for the plant and soil sciences. Taylor and Francis, Boca Raton, FL.

Thompson, W.H. 2002. Test methods for the examination of composting and compost. US Composting Council, Holbrook, NY.

Verdonck, O., R. Penninck, and M.D. Boodt. 1984. Physical properties of different horticultural substrates. Intl. Soc. Hort. Sci. Acta Horticulturae 150:155-160.

Wada, S. 2005. Nursery container weeds response to modification of substrate $\mathrm{pH}$, substrate particle size and applied nitrogen form, p. 72-76. Oregon State Univ., Corvallis, MS Thesis.

Weber, J.B. 1990. Behavior of dinitroaniline herbicides in soils. WeedTech. 4:394-406.

Weber, J.B., L.R. Swain, H.J. Strek, and J.L. Sartori. 1986. Herbicide mobility in soil leaching columns, p. 189-200. In: N.D. Camper (ed.). Research methods in weed science. Southern Weed Sci. Soc., Champaign, IL.

Wehtje, G., C.H. Gilliam, and S.C. Marble. 2012 Duration of flumioxazin-based weed control in container-grown nursery crops. Weed Technol. 26(4):679-683.

Wehtje, G.R., J.E. Altland, C.H. Gilliam, S.C. Marble, A.J. Van Hoogmoed, and G.B. Fain. 2009 . Weed growth and efficacy of pre-applied herbicides in alternative rooting substrates used in container-grown nursery crops. Weed Technol. 23(3):455-459.

Wu, C.H. and P.W. Santelman. 1975. Comparison of different soil leaching techniques with four herbicides. Weed Sci. 23:508-511. 